\title{
Characterization of Cupriavidus eutrophus B-10646 Culture Synthesizing Polyhydroxyalkanoates Grown on Sugars And Lipidic Substrates
}

\author{
Natalia O. Zhila ${ }^{\text {a*},}$ \\ Tatiana G. Volova ${ }^{a, b}$ and Galina S. Kalacheva ${ }^{a}$ \\ ${ }^{a}$ Institute of Biophysics SB RAS \\ 50/50 Akademgorodok, Krasnoyarsk, 660036, Russia \\ ${ }^{b}$ Siberian Federal University \\ 79 Svobodny, Krasnoyarsk, 660041, Russia
}

Received 09.05.2014, received in revised form 24.05.2014, accepted 04.06.2014

Growth, polyhydroxyalkanoates (PHAs) accumulation and total fatty acid composition of the lipids of Cupriavidus eutrophus B-10646 were studied, using various carbon sources (fructose, glucose, oleic acid, sunflower seed oil). The best substrates for biomass production (7.8-8.6 g/l) and polymer synthesis (7.3-7.9 g/l) were sugars and oleic acid. Bacterial cells grown on sugars and sunflower seed oil synthesized only homopolymer poly(3-hydroxybutyrate). 3-hydroxyvalerate (2.0-4.2 mol. \%) was identified in polymer when Cupriavidus eutrophus used oleic acid as sole carbon source. Study of total fatty acid composition of lipids showed that major fatty acids were palmitic (16:0), palmitoleic

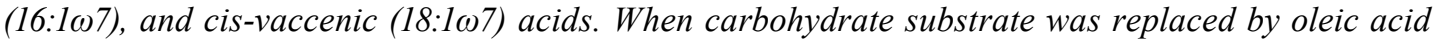
or sunflower seed oil, the proportion of oleic acid in the total fatty acids increased considerably. In addition to that, the lipid fatty acids of bacterial cells grown on sunflower seed oil also contained linoleic acid, which is the major acid of sunflower seed oil.

Keywords: Cupriavidus eutrophus, fatty acids, polyhydroxyalkanoates, oleic acid, sunflower seed oil.

(C) Siberian Federal University. All rights reserved

* Corresponding author E-mail address: 1hab@ibp.ru 


\title{
Характеристика культуры Cupriavidus eutrophus B-10646, синтезирующей полигидроксиалканоаты \\ при росте на сахарах и липидных субстратах
}

\author{
Н.О. Жила ${ }^{a}$, \\ Т.Г. Волова ${ }^{\text {a, }, ~}$, Г.С. Калачева ${ }^{a}$ \\ ${ }^{a}$ Институт биофизики СО РАН \\ Россия, 660036, Красноярск, Академгородок, 50/50 \\ ${ }^{6}$ Сибирский федеральный университет \\ Россия, 660041, Красноярск, пр. Свободныий, 79
}

Исследованы рост, синтез полимера, изменения в общем жирнокислотном составе липидов Cupriavidus eutrophus B-10646 при культивировании на сахарах (фруктоза, глюкоза) и липидных субстратах (олеиновая кислота, подсолнечное масло). Наилучшими субстратами для роста бактерий (7.8-8.6 г/л) и синтеза полимера (7.3-7.9 г/л) были сахара и олеиновая кислота. При росте на всех субстратах, за исключением олеиновой кислоты, бактерии синтезировалигомополимер поли(3-гидроксибутират). В составе полимера, полученного при росте на олеиновой кислоте, идентифицированы включения 3-гидроксивалерата (2.0-4.2 мол. \%). Исследование общего жирнокислотного (ЖК) состава липидов показало, что основными жирными кислотами были


замена углеводного субстрата на олеиновую кислоту или подсолнечное масло отразилась на спектре общего ЖК состава липидов бактерий, приводя к значительному увеличению олеиновой кислоты. Кроме того, в составе ЖК липидов бактерий, выращенных на растительном масле, обнаружена и линолевая кислота, являющаяся основной кислотой подсолнечного масла.

Ключевые слова: Cupriavidus eutrophus, жирные кислоты, полигидроксиалканоаты, олеиновая кислота, подсолнечное масло.

\section{Введение}

Полигидроксиалканоаты (ПГА) - термопластические полиэфиры, синтезируемые различными бактериями в качестве внутриклеточного запасного материала в условиях лимитирования роста питательными элементами (например, азотом, фосфором) и при избыточном содержании источника углерода. Cupriavidus necator (ранее Ralstonia eutropha) считают одним из наиболее исследуемых видов бактерий среди ПГА-продуцирующих микроорганизмов. В последние годы изучению ПГА уделяется огромное внимание бла- годаря их потенциальному применению в различных областях - от сельского хозяйства до медицины, так как по сравнению с обычными пластиками, получаемыми из нефти, ПГА разрушаются в аэробных/анаэробных условиях и являются биосовместимыми материалами. Однако сравнение ПГА с другими эквивалентными коммерциализированными материалами (например, синтетические полимеры или нефтехимические пластики) показывает, что ПГА достаточно дорогие материалы. Хотя технология культивирования и процесс экстракции полимера с каждым 
годом совершенствуются, в промышленном масштабе производство ПГА пока не может соревноваться с синтетическими пластиками из-за высокой стоимости субстратов для культивирования. В этой связи в настоящее время растет потребность в новых штаммах, способных синтезировать ПГА при росте на недорогих ростовых субстратах. На текущий момент большинство коммерческих пластиков изготовлено с использованием невозобновляемых ресурсов. Неизбежно, что эти ресурсы со временем будут исчерпаны, поэтому многие компании проводят исследования по получению пластиков из возобновляемых источников углерода. Многообещающее направление для получения ПГА - использование растительных масел или жирных кислот (ЖK).

В настоящее время потенциальными источниками углерода для получения ПГА считаются такие растительные масла, как оливковое, кукурузное, соевое, рапсовое, пальмовое, подсолнечное, а также жирные кислоты (главным образом олеиновая) и богатые липидами отходы пищевой промышленности (Sudesh et al., 2011; Arcos-Hernandez et al., 2012; Nikodinovic-Runic et al., 2013). Растительные масла и жирные кислоты по сравнению с другими общепринятыми источниками углерода, такими как сахара, имеют преимущество, заключающееся в более низкой стоимости (Akiyama et al., 2003). Кроме того, растительные масла обеспечивали более высокие урожаи как клеточной биомассы, так и ПГА (0.6-0.8 г ПГА/г используемого масла), так как они содержат больше углерода на единицу веса по сравнению с сахарами (Akiyama et al., 2003). Урожай ПГА при росте на глюкозе составлял всего лишь 0.32-0.48 г ПГА/г используемой глюкозы (Yamane, 1992).

В качестве потенциальных источников углерода для роста бактерий и синтеза по- лимера исследуют различные масла. Kahar et al. (2004) использовали соевое масло как единственный источник углерода при выращивании $C$. necator H16 и его рекомбинантного штамма (несущего ген синтазы ПГА из Aeromonas caviae) для синтеза гомополимера поли-3-гидроксибутирата (ПЗГБ) и сополимера поли(3-гидроксибутират-со-

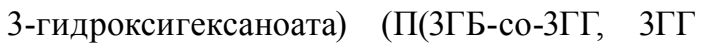
5 мол\%)). На данном субстрате авторы получали высокие урожаи ПГА (от 0.72 до 0.76 г ПГА/г соевого масла) (Fukui and Doi, 1998; Kahar et al., 2004). Высокие выходы полимера также были получены при культивировании рекомбинантного $C$. necator H16 на пальмовом масле. При росте $C$. necator H16 на подсолнечном масле концентрация клеток составляла 4.7 г/л, содержание полимера - 72 \% от биомассы (Lee et al., 2008). Аналогичные результаты получены этими же авторами при pocте $C$. necator $\mathrm{H} 16$ на оливковом, кокосовом и неочищенном пальмовом маслах. Самый лучший рост - 5.5-5.6 г/л - и накопление полимера - 75-77 \% от биомассы - наблюдали при росте $C$. necator $\mathrm{H} 16$ на пальмовом масле (Lee et al., 2008). Однако другой штамм Cupriavidus sp. USMAA2-4 не использовал данный субстрат в качестве источника углерода (Iqbal and Amirul, 2014). Отходы рапсового масла применяли для продукции поли(3гидроксибутирата-со-3-гидроксивалерата) (П(ЗГБ-со-3ГВ)) у C. necator при росте на среде, содержащей пропанол (Obruca et al., 2010). Использованное масло после жарки успешно превращалось в ПЗГБ у C. necator (Verlinden et al., 2011). До 80 \% ПГБ от биомассы продуцировалось Alcaligenes eutrophus DSM 545 и его рекомбинантным штаммом при росте на различных растительных маслах (Fukui and Doi, 1998). Loo et al. (2005) исследовали пригодность масла из сердцевины пальмового ореха, неочищенного пальмового масла в ка- 
честве субстратов для синтеза ПГА бактерией Wautersia eutropha PHB-4, несущей ген синтазы из A. caviae. Урожай сополимера П(ЗГБсо-ЗГГ, 5 мол\% ЗГГ) составлял от 1.5 до 6.9 г/л (Bhubalan et al., 2008; Loo et al., 2005). При росте на рапсовом масле $W$. eutropha ATCC 17699 синтезировала среднецепоченые ПГА (до $90 \%$ от биомассы) (Lopez-Cuellara et al., 2011).

Еще одним перспективным субстратом для синтеза полимера является олеиновая кислота. Marangoni et al. (2000) показали, что использование олеиновой кислоты как дополнительного источника углерода приводило к увеличению продукции ПГА у глюкозоутилизирующего штамма $R$. eutropha DSM 545. Добавление олеиновой кислоты в пределах 0.9-3.0 г/л как вспомогательного субстрата также приводило к увеличению концентрации биомассы в 2-7 раз по сравнению с ростом на глюкозе у этого же штамма (Grigull et al., 2008). Более высокие выходы биомассы и ПГА в 1.5 и 1.3 раза соответственно, при росте на смеси фруктозы и олеиновой кислоты по сравнению с ростом на фруктозе также наблюдали у штамма Alcaligenes sp. NCIM No. 5085 (Srivastava and Tripathi, 2013). Максимальный урожай биомассы и содержание полимера при росте Cupriavidus sp. USMAA2-4 на олеиновой кислоте и фруктозе составляли 7.1 г/л и $59 \%$ от биомассы и 4.3 г/л и $35 \%$ от биомассы соответственно (Iqbal and Amirul, 2014). Аналогичные результаты получены для штамма Cupriavidus sp. USMAHM13. При росте на олеиновой кислоте биомасса и содержание полимера составляли 11.5 г/л и $48 \%$ от биомассы соответственно, тогда как на сахарах биомасса не превышала 5 г/л, а полимер - $30 \%$ от биомассы (Ramachandran and Amirul, 2013). При росте штамма Cupriavidus sp. USMAA2-4 на различных жирных кислотах как основном источнике углерода и 1-пен- танола наилучшие показатели биомассы и полимера получены при культивировании на олеиновой кислоте (8.1 г/л и $56 \%$ от биомассы) (Shantini et al., 2013). Показана возможность получения сополимеров П(ЗГБ-со-4ГБ) при росте штамма Cupriavidus sp. USMAA1020 (DSM 19416) на олеиновой кислоте с предшественниками 4ГБ: $\gamma$-бутиролактоном, 1,4-бутандиолом, 1,6 - гександиолом с высокими выходами биомассы и полимера (Huong et al., 2014) и трехкомпонентных полимеров П(ЗГБco-3ГВ-со-4ГБ) (Muzaiyanah and Amirul, 2013) и П(ЗГБ-со-ЗГВ-со-4ГБ) (Ramachandran et al., 2011) бактериями Cupriavidus sp. USMAA2-4 при росте на олеиновой кислоте с предшественниками 4ГВ, ЗГВ и 4ГБ, соответственно, $\gamma$-валеролактоне, 1-пентаноле и 1,4-бутандиоле.

В последние годы показано, что синтез ПГА у $R$. eutropha тесно связан с метаболизмом липидов, особенно если в качестве субстратов используются или длинноцепочечные жирные кислоты, или растительные масла (Riedel et al., 2014). Бактерии R. eutropha относятся к наиболее изученным организмам в отношении синтеза ПГА, однако данные по составу липидов и жирных кислот весьма ограничены, несмотря на то что липидный профиль интенсивно используется в хемотаксономии бактерий, а анализ состава жирных кислот является общепризнанным быстрым методом идентификации видов (Buyer, 2002). Нам известно только несколько работ о составе липидов и жирных кислот водородокисляющих бактерий Hydrogenomonas eutropha H-16 (Thiele, 1971; Thiele et al., 1972; Thiele et al., 1977) и нескольких штаммов Ralstonia (Galbraith et al., 1999), свидетельствующих о том, что состав липидов и жирных кислот этого организма характерен для грамотрицательных бактерий (Cronan and Rock, 1996). 
Таким образом, целью работы было исследование роста, синтеза полимера и ЖК состава у Cupriavidus eutrophus B-10646 при росте на липидных субстратах.

\section{Материалы и методы}

В работе использовали штамм водородокисляющих бактерий Cupriavidus eutrophus В-10646, зарегистрированный во Всероссийской коллекции промышленных микроорганизмов (ВКПМ). Данный штамм обладает широким органотрофным потенциалом и может применять в качестве источников углерода различные вещества. Данный штамм устойчив к концентациям 3-5 г/л в культуральной среде следующих органических субстратов: валериановая кислота, гексановая кислота, $\gamma$-бутиролактон - и способен использовать их для синтеза сополимеров ПГА, содержащих коротко- и среднецепочечные мономеры (Волова, Шишацкая, 2012).

Бактерии выращивали в периодическом двустадийном режиме, разработанном ранее для синтеза ПГА (Волова и др., 1996). Посевной материал исследуемого штамма получали ресуспендированием музейной культуры, хранящейся на агаризованной среде. Далее музейную культуру выращивали в жидкой минеральной среде в стеклянных колбах объемом 1 л при коэффициенте заполнения 0,5 c использованием термостатируемого шейкераинкубатора «Incubator Shaker Innova ${ }^{\circledR}$ серии 44 («New Brunswick Scientific», США) при $30{ }^{\circ} \mathrm{C}$ и $200 \mathrm{rpm}$. Для выращивания бактерий использовали среду Шлегеля (Schlegel et al., 1961): $\mathrm{Na}_{2} \mathrm{HPO}_{4} \cdot \mathrm{H}_{2} \mathrm{O}-9.1 ; \mathrm{KH}_{2} \mathrm{PO}_{4}-1.5$; $\mathrm{MgSO}_{4} \cdot \mathrm{H}_{2} \mathrm{O}-0.2 ; \mathrm{Fe}_{3} \mathrm{C}_{6} \mathrm{H}_{5} \mathrm{O}_{7} \cdot 7 \mathrm{H}_{2} \mathrm{O}-0.025$; $\mathrm{NH} 4 \mathrm{Cl}$ - 1 (г/л). Микроэлементы вводили по прописи Хоагланда из расчёта 3 мл стандартного раствора на 1 л среды. Стандартный раствор содержит: $\mathrm{H}_{3} \mathrm{BO}_{3}-0.288 ; \mathrm{CoCl}_{2} \cdot 6 \mathrm{H}_{2} \mathrm{O}-$ 0.030; $\mathrm{CuSO}_{4} \cdot 5 \mathrm{H}_{2} \mathrm{O}-0.08 ; \mathrm{MnCl}_{2} \cdot 4 \mathrm{H}_{2} \mathrm{O}-0.008$;

$$
\begin{aligned}
& \mathrm{ZnSO}_{4} \cdot 7 \mathrm{H}_{2} \mathrm{O}-0.176 ; \mathrm{NaMoO}_{4} \cdot 2 \mathrm{H}_{2} \mathrm{O}-0.050 ; \\
& \mathrm{NiCl}_{2}-0.008 \text { (г/л). }
\end{aligned}
$$

Динамика накопления биомассы клеток, ПГА и липидов C. eutrophus B-10646 исследована в гетеротрофном режиме выращивания. Продолжительность культивирования составляла 72 ч. В качестве источников углерода использовали одно из следующих веществ: глюкозу, фруктозу, олеиновую кислоту или подсолнечное масло (состав масла: С16:0 -

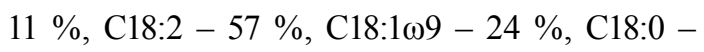
$8 \%$. Начальная концентрация субстратов составляла 10 г/л. По ходу роста культуры и исчерпания субстрата делали добавки соответствующих субстратов в культуру в концентрациях, аналогичных исходным.

Урожай биомассы клеток в ходе развития культуры бактерий регистрировали по весу сухого вещества и оптическим показателям культуры. Концентрацию фруктозы в среде определяли резорциновым методом (Ермаков и др., 1972), концентрацию глюкозы в среде - спектрофотометрически (490 нм) с использованием кита Фотоглюкоза (Impact Ltd., Россия). Концентрацию олеиновой кислоты определяли после экстракции на хроматомасс-спектрометре (7890/5975C, Agilent Technologies, USA), содержание подсолнечного масла - весовым методом. Содержание и состав полимера определяли хроматографией метиловых эфиров жирных кислот с применением хромато-масс-спектрометра Agilent Technologies 7890A (США). Молекулярную массу и молекулярно-массовое распределение полимера исследовали с использованием хроматографа для гельпроникающей хроматографии Agilent Technologies 1260 Infinity (США) относительно полистироловых стандартов (Fluka, Швейцария, Германия). Находили средневесовую $\left(\mathrm{M}_{\mathrm{B}}\right)$ и среднечисловую $\left(\mathrm{M}_{\mathrm{H}}\right)$ молекулярную массу, а также полидисперсность (ПД = $\mathrm{M}_{\mathrm{z}} / \mathrm{M}_{\mathrm{H}}$ ). 
Основные методы анализа липидов и жирных кислот подробно описаны в наших работах (Калачева, Волова, 2007; Kalacheva et al., 2002). Липиды экстрагировали из биомассы смесью хлороформ-метанол (2:1) по методу Фолча. Бактерии, выращенные на среде с олеиновой кислотой и подсолнечным маслом, предварительно отмывали от субстратов кратковременной обработкой гексаном. В конечном экстракте полимер отделяли от липидов осаждением при добавлении двойного объема гексана. Для определения общего ЖК состава липидов к биомассе бактерий добавляли $1 \mathrm{~N}$ КОН в 95\%-ном этаноле и нагревали на водяной бане с обратным холодильником. После этого добавляли двойной объем дистиллированной воды и жирные кислоты экстрагировали гексаном. Далее проводили метанолиз для получения метиловых эфиров жирных кислот (МЭЖК) (Калачева, Волова, 2007). Метанолиз жирных кислот проводили в смеси метанола и серной кислоты (50:1 по объему) в течение 2 ч при $90{ }^{\circ} \mathrm{C}$. Анализ МЭЖК проводили на хромато-масс-спектрометре GC-MS 7890/5975C (Agilent Technologies, USA). Условия анализа: газ-носитель - гелий, скорость 1 мл/мин; температура ввода пробы $220{ }^{\circ} \mathrm{C}$; начальная температура хроматографирования $120^{\circ} \mathrm{C}$; подъем температуры до $230{ }^{\circ} \mathrm{C}$ со скоростью $5{ }^{\circ} \mathrm{C} /$ мин, изотермальный режим 5 мин и последующий подъем температуры до $310{ }^{\circ} \mathrm{C}$ со скоростью $10{ }^{\circ} \mathrm{C} /$ мин, изотермальный режим 3 мин; температура детектора $230{ }^{\circ} \mathrm{C}$; температура источника ионов $150{ }^{\circ} \mathrm{C}$; электронный удар при $70 \mathrm{eV}$; определение фрагментов с атомными массами от 30 до $550 \mathrm{amu}$ при 0.5 с/скан. Идентификацию ЖК проводили по масс-спектрам и сравнением их времен удерживания с таковыми имеющихся стандартов (Serva, Germany and Sigma, U.S.). Положение двойных связей в моноеновых кислотах определяли после получения ди- метилдисульфидных (ДМДС) производных соответствующих жирных кислот (Christie, 1989).

Для получения фракции полярных липидов липидные экстракты разделяли микротонкослойной хроматографией (сорбент - силикагель-гипс на стеклянных пластинках) в системе для нейтральных липидов (гексан : диэтиловый эфир : уксусная кислота=85 : $15: 1$, по объему (Кейтс, 1975; Svetashev and Vaskovsky, 1972). Стартовую полоску, соответствующую фракции фосфолипидов, помещали вместе с силикагелем в пробирку и экстрагировали смесью хлороформ : этанол ( $2: 1$ по объему) и далее проводили метанолиз для получения МЭЖК.

Эксперименты проведены в трех повторностях. Статистический анализ выполнен с использованием Microsoft Excel. Приведены арифметические средние и их стандартные ошибки.

\section{Результаты и обсуждение}

Самые высокие выходы биомассы бактерий (7.8-8.6 г/л) и полимера (7.3-7.9 г/л) получены при использовании в качестве ростовых субстратов сахаров и олеиновой кислоты (табл. 1), что согласуется с данными других авторов (Muzaiyanah and Amirul, 2013). При использовании в качестве субстрата подсолнечного масла конечные концентрация биомассы и полимера были ниже и не превышали 3.9 и 1.8 г/л соответственно. Известно, что при гидролизе масла липазой образуются свободные жирные кислоты и глицерин. В подсолнечном масле линолевая кислота составляет 54 \% от суммы ЖК. Возможно, что линолевая кислота оказывает ингибирующее действие на рост клеток и синтез полимера, т.к. показано, что ингибирующее влияние ненасыщенных жирных кислот увеличивается с ростом двойных связей в молекуле. Ингибирующее 


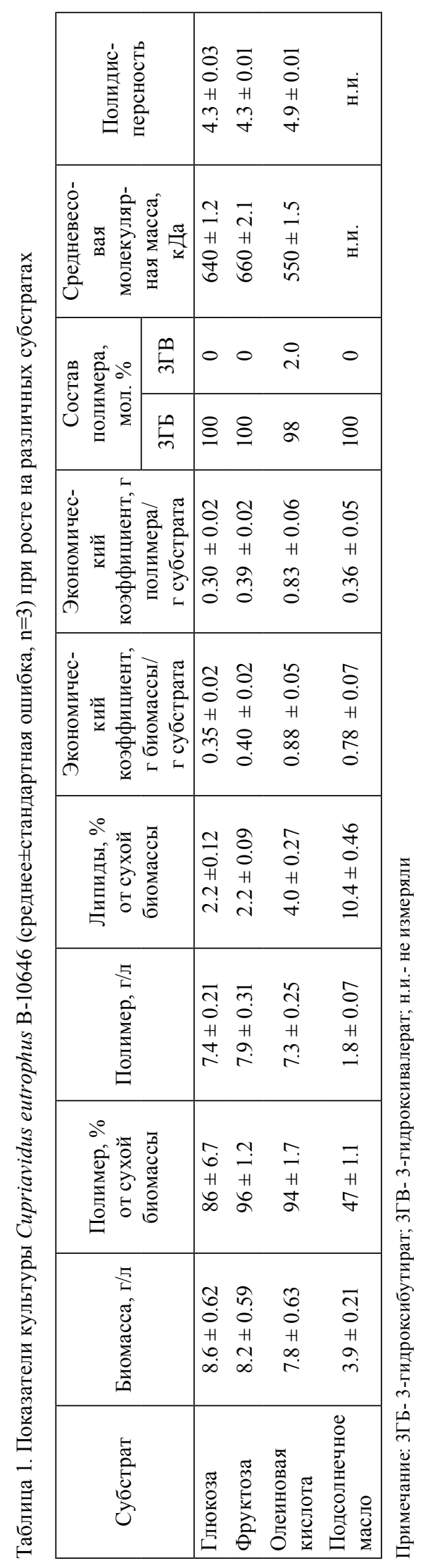


действие линолевой кислоты на накопление биомассы и полимера отмечено для культуры Sphaerotilus natans 0B17 (Pseudomonas sp.) (Lo et al., 2005). Расчет экономического коэффициента (Y) показал, что при культивировании Cupriavidus eutrophus B-10646 на сахарах Y составлял 0.35-0.40 г биомассы/г используемого субстрата, что практически в 2 раза ниже, чем при культивировании на олеиновой кислоте и подсолнечном масле, что хорошо согласуется с ранее полученными результатами других авторов (Yamane et al., 1992; Akiyama et al., 2003).

Протеобактерии, относящиеся к грамотрицательным бактериям, характеризуются ограниченным набором жирных кислот, в состав которых входят насыщенные, моноеновые, циклопропановые и гидроксикислоты с длиной цепи от 12 до 18 атомов углерода (Cronan, Rock, 1996; Parsons, Rock, 2013). Исследованные нами бактерии C. eutrophus В-10646 относятся к грамотрицательным протеобактериям, а общий ЖК состав липидов бактерий C. eutrophus B-10646, выращенных на сахарах, был характерен для этой группы микроорганизмов и мало отличался от ранее полученных данных для других штаммов $R$. eutropha В5786 и В8562 (Волова и др., 2005; Калачева, Волова, 2007). При выращивании на сахарах спектры общего ЖК состава липидов схожи и представлены жирными кислотами с длиной цепи от 12 до 19 атомов углерода (табл. 2). Основной насыщенной кислотой является пальмитиновая (16:0), составляющая 51-52 \% от суммы жирных кислот. Доля миристиновой кислоты (14:0) в спектре ЖК составляла около $8 \%$, стеариновой (18:0) - $2 \%$. Остальные насыщенные кислоты (12:0, 15:0, 17:0) отнесены к минорным компонентам, и их доля составляла 0.2-0.3\%. Доминирующими моноеновыми кислотами были пальмитолеи-

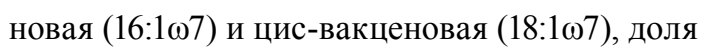

которых в общем ЖК-спектре составляла 10 12 и 9-10\%. Обнаружены изомеры соответствующих моноеновых кислот, доля которых в общем ЖК-спектре составляла для C16:1 и C18:1 порядка 1 \%. Относительное содержание циклопропановых кислот колебалось от 1 до $2 \%$. Соотношение насыщенных кислот к ненасыщенным составляло 3.42-3.88. Полученные данные совпадали с идентификацией ЖК состава Ralstonia eutropha в работе Osterhout et al. (1998), но отличались от данных для Ralstonia eutropha H850 (Kim et al., 2002) и Cupriavidus necator JMP134 (Lerch et al., 2007). В этих работах показано, что основными изомерами гексадеценовой и октадеце-

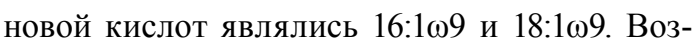
можно, это объясняется разными штаммами или недостаточно корректными методами идентификации положения двойных связей в ненасыщенных алифатических цепях.

Замена углеводного субстрата на олеиновую кислоту или подсолнечное масло отразилась на общем ЖК-составе липидов у данного штамма. Доля минорного изомера 18:1 19 (олеиновая кислота) возросла с 0.2 до 17-23 \% (табл. 2). Достоверность идентификации этой кислоты подтверждена масс-спектрометрией диметилдисульфидных (ДМДС) производных метиловых эфиров моноеновых кислот. Кроме того, в составе ЖК липидов бактерий, выращенных на растительном масле, обнаружена и линолевая кислота (5.73 \%), являющаяся основной кислотой подсолнечного масла. Для подтверждения правильности результатов экстрагируемые липиды были разделены тонкослойной хроматографией, собрана фракция фосфолипидов и проанализирован ЖК-состав, который практически не отличался от результатов, обсужденных выше (неопубликованные данные). При выращивании бактерий Alcaligenes sp. S-XJ-1 на различных растительных маслах в работе (Huang et al., 
Natalia O. Zhila, Tatiana G. Volova... Characterization of Cupriavidus eutrophus B-10646 Culture Synthesizing...

Таблица 2 Общий жирнокислотный состав липидов Cupriavidus eutrophus B-10646 (\% от суммы ЖК, среднее \pm стандартная ошибка, $\mathrm{n}=3$ ) при росте на различных субстратах

\begin{tabular}{|c|c|c|c|c|}
\hline Жирная кислота & Глюкоза & Фруктоза & Олеиновая кислота & $\begin{array}{c}\text { Подсолнечное } \\
\text { масло }\end{array}$ \\
\hline $12: 0$ & $0.20 \pm 0.01$ & $0.21 \pm 0.01$ & $1.51 \pm 0.01$ & $0.06 \pm 0.02$ \\
\hline 14:0 & $7.90 \pm 0.63$ & $7.82 \pm 0.45$ & $8.00 \pm 0.74$ & $4.03 \pm 0.38$ \\
\hline $15: 0$ & $0.15 \pm 0.03$ & $0.18 \pm 0.12$ & $0.30 \pm 0.05$ & $0.14 \pm 0.01$ \\
\hline $16: 1 \omega 7$ & $12.44 \pm 0.83$ & $9.97 \pm 0.85$ & $7.22 \pm 0.93$ & $2.66 \pm 0.19$ \\
\hline $16: 1 \omega 5$ & $0.98 \pm 0.21$ & $0.86 \pm 0.13$ & $0.84 \pm 0.06$ & $0.23 \pm 0.1$ \\
\hline 16:0 & $51.15 \pm 5.24$ & $52.37 \pm 4.34$ & $35.89 \pm 2.17$ & $36.82 \pm 2.85$ \\
\hline$C-17: 0^{a}$ & $2.34 \pm 0.32$ & $1.17 \pm 0.07$ & $0.42 \pm 0.16$ & $0.73 \pm 0.8$ \\
\hline $17: 0$ & $0.20 \pm 0.20$ & $0.32 \pm 0.02$ & $0.42 \pm 0.03$ & $0.23 \pm 0.01$ \\
\hline $18: 2$ & H.o. & H.о. & H.O. & $5.73 \pm 0.42$ \\
\hline $18: 1 \omega 9$ & $0.15 \pm 0.02$ & $0.15 \pm 0.00$ & $22.62 \pm 1.82$ & $20.45 \pm 1.93$ \\
\hline $18: 1 \omega 7$ & $9.02 \pm 0.72$ & $9.51 \pm 0.74$ & $10.15 \pm 1.12$ & $7.27 \pm 0.68$ \\
\hline 18:0 & $1.86 \pm 0.19$ & $1.93 \pm 0.12$ & $4.07 \pm 0.31$ & $10.71 \pm 1.34$ \\
\hline$C-19: 0^{\mathrm{a}}$ & следы & следы & следы & следы \\
\hline $14: 02-\mathrm{OH}$ & $1.21 \pm 0.02$ & $1.83 \pm 0.12$ & $0.81 \pm 0.06$ & $1.70 \pm 0.21$ \\
\hline 14:0 $\beta-\mathrm{OH}$ & $12.06 \pm 1.11$ & $12.88 \pm 0.69$ & $7.61 \pm 0.68$ & $8.94 \pm 0.58$ \\
\hline 16:0 2-OH & $0.26 \pm 0.03$ & $0.66 \pm 0.05$ & $0.09 \pm 0.009$ & $0.26 \pm 0.02$ \\
\hline $16: 0 \beta-\mathrm{OH}$ & $0.07 \pm 0.00$ & $0.14 \pm 0.01$ & $0.05 \pm 0.00$ & $0.04 \pm 0.00$ \\
\hline $\begin{array}{c}\Sigma \text { насыщ. }{ }^{\sigma} / \\
\sum_{\text {ненасыщ. }}\end{array}$ & $3.42 \pm 0.27$ & $3.88 \pm 0.02$ & $1.44 \pm 0.09$ & $1.75 \pm 0.09$ \\
\hline
\end{tabular}

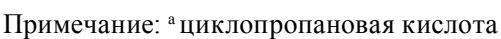

${ }^{6}$ насыщ. - насыщенные жирные кислоты, включающие циклопропановую кислоту и ОН-кислоты

${ }^{\text {в } н е н а с ы щ . ~-~ н е н а с ы щ е н н ы е ~ ж и р н ы е ~ к и с л о т ы ~}$

н.о. - не обнаружена.

2012) отмечена большая вариабельность состава жирных кислот, выделенных из целых клеток после их омыления. Мембранные липиды обогащались жирными кислотами, свойственными тем маслам, которые использовались в качестве субстрата. Как известно, многие штаммы Ralstonia eutropha растут на растительных маслах и жирных кислотах (Sudesh et al., 2011). Эти бактерии выделяют липазу, которая разрушает экзогенные масла, при этом свободные ЖК активно переносятся через клеточную стенку и цитоплазматическую мембрану и активизируются коэнзимом А. Экзогенные ЖК в виде ацил-КоА переправляются в $\beta$-окисление и через этот путь используются для метаболических нужд клетки. По всей вероятности, часть ацильных цепей с ацил-КоА непосредственно переносится в фосфолипиды клеточных мембран, в результате чего состав ЖК модифицируется экзогенными жирными кислотами. Модификацию состава мембранных липидов экзогенными жирными кислотами наблюдали и у $E$. coli (Cronan, Rock, 1996), т.к. донорами ацильных цепей в синтезе фосфолипидов у этих бактерий могут быть не только ацил-АПБ, но и ацил-КоА (Parsons, Rock, 2013).

При выращивании бактерий C. eutrophus B-10646 максимальное содержание полимера (86-96 \% от веса сухой биомассы) получено при культивировании бактерий на сахарах и олеиновой кислоте (табл. 1). При росте на 
подсолнечном масле содержание полимера не превышало 47 \% от веса сухой биомассы. Помимо общего выхода исследованы состав и молекулярно-массовые характеристики ПГА, синтезируемых бактериями C. eutrophus В-10646 (табл. 1). При росте на всех субстратах, за исключением олеиновой кислоты, синтезированный полимер был гомополимером 3-гидроксимасляной кислоты (ПЗГБ). При выращивании C. eutrophus B-10646 на олеиновой кислоте в составе сополимера идентифицированы включения 3-гидроксивалерата (2.02-4.20 мол. \%). Появление 3-гидроксивалерата в составе полимера, выделенного из биомассы Alcaligenes sp. NCIM No 5085, также наблюдали при культивировании данного штамма на олеиновой кислоте (Srivastava and Tripathi, 2013). Синтез гомополимера П(ЗГБ) C. eutrophus B-10646 на подсолнечном масле согласуется с данными других авторов, полученных для штамма C.necator H16. Показано, что при росте на всех исследуемых маслах, включая подсолнечное масло, данный штамм синтезировал гомополимер ПЗГБ (Fukui and Doi, 1998; Lee et al., 2008). Образцы полимеpa, отобранные из проб клеточной биомассы, имели значение средневесовой молекулярной массы (Мв) 640-660 кДа и 510-550 кДа при росте бактерий, соответственно, на сахарах и олеиновой кислоте.

\section{Заключение}

Таким образом, исследованы урожай, выходы ПГА, общий жирнокислотный состав липидов у штамма водородокисляющих бактерий C. eutrophus B-10646 и показано влияние на эти показатели типа углеродного субстрата. Обнаружено, что наилучшими субстратами для роста бактерий и синтеза полимера являются сахара и олеиновая кислота. Установлено, что используемые для культивирования бактерий субстраты могут существенно изменить состав ЖК липидов бактерий, что важно при описании их физиолого-биохимических характеристик.

\section{Список литературы}

1. Волова Т.Г., Шишацкая Е.И. (2012) Штамм бактерий ВКПМ В-10646 - продуцент полигидроксиалканоатов и способ их получения. Патент РФ № 2439143.

2. Волова Т.Г., Калачева Г.С., Константинова В.М. (1996) Способ получения гетерополимера $\beta$-оксимасляной и $\beta$-оксивалериановой кислот. Патент № 2051968.

3. Волова Т.Г., Кожевников И.В., Долгополова Ю.Б., Трусова М.Ю., Калачева Г.С., Арефьева Ю.В. (2005) Физиолого-биохимические свойства и способность к синтезу полиоксиалканоатов у глюкозоусваивающего штамма водородных бактерий Ralstonia eutropha B8562. Микробиология 74: 788-794.

4. Ермаков А.И., Арасимович В.В., Смирнова-Иконникова М.И., Ярош Н.П., Луковникова Г.А. (1972) Методы биохимического исследования растений. Ленинград: Колос, 456 с.

5. Калачева Г.С., Волова Т.Г. (2007) Состав жирных кислот липидов Wautersia eutropha в условиях активного синтеза полигидроксиалканоатов. Микробиология 76: 608-614.

6. Кейтс М. (1975) Техника липидологии. Выделение, анализ и идентификация липидов. М.: Мир, 325 с.

7. AkiyamaM., Tsuge T., Doi Y.(2003) Environmental life cycle comparison of polyhydroxyalkanoates produced from renewable carbon resources by bacterial fermentation. Polym. Degrad. Stab. 80: 183-194. 
8. Arcos-Hernandez M.V., Pratt S., Laycock B., Johansson P., Werker A., Lant P.A. (2013) Waste activaged sludge as biomass for production of commercial-grade polyhydroxyalkanoates (PHA). Waste and Biomass Valorization 4: 117-127.

9. Bhubalan K., Lee W.H., Loo C.Y., Yamamoto T., Doi Y., Sudesh K. (2008) Controlled biosynthesis and characterization of poly(3-hydroxybutyrate-co-3-hydroxyvalerate-co-3-hydroxyhexanoate) from mixtures of palm kernel oil and 3HV-precursors. Polym. Degrad. Stab. 93: 17-23.

10. Buyer J.S. (2002) Identification of bacteria from single colonies by fatty acid analysis. J. Microb. Methods 48: 259-265.

11. Christie W.W. (1989) Gas chromatography and lipids. A practical guide. Ayr: The Oily Press, 307 p.

12. Cronan J.E. Jr., Rock C.O. (1996) Biosynthesis of membrane lipids. In: Neidhardt F.C., Curtiss R., Ingraham J.L., Lin E.C.C., Low K.B., Magasanic B., Reznokoff W.S., Riley M., Schaechter M., Umbarger H.E. (eds) Esherichia coli and Salmonella: cellular and molecular biology, 2nd edn. American Society for Microbiology, Washington DC, p. 612-636.

13. Fukui T., Doi Y. (1998) Efficient production of polyhydroxyalkanoates from plant oils by Alcaligenes eutrophus and its recombinant strain. Appl. Microbiol. Biotechnol. 49: 333-336.

14. Galbraith L., Jonsson M.H., Rudhe L.C., Wilkinson S.G. (1999) Lipids and fatty acids of Burkholeria and Ralstonia species. FEMS Microbiol. Lett. 173: 359-364.

15. Grigull V.H., da Silva D.D., Garcia M.C.F., Furlan S.A., Pezzin A.P.T., Schneider A.L.S., Aragão G.F. (2008) Production and characterization of poly(3-hydroxybutyrate) from oleic acid by Ralstonia eutropha. Food Technol. Biotechnol. 46: 223-228.

16. Huang X.F., Li M.X., Lu L.J., Yang S., Liu J. (2012) Relationship of cell-wall bound fatty acids and the demulsification efficiency of demulsifying bacteria Alcaligenes sp. S-XJ-1 cultured with vegetable oils. Biores. Technol. 104: 530-536.

17. Huong K.H., Yahya A.R.M., Amirul A.A. (2014) Pronounced synergistic influence of mixed substrate cultivation on single step copolymer P(3HB-co-4HB) biosynthesis with a wide range of 4HB monomer composition. J. Chem. Technol. Biotechnol. 89: 1023-1029.

18. Iqbal N.Md., Amirul A.A. (2014) Synthesis of P(3HB-co-4HB) copolymer with target-specific 4HB molar fractions using combinations of carbon substrates. J. Chem. Technol. Biotechnol. 89: 407-418.

19. Kahar P., Tsuge T., Taguchi K., Doi Y. (2004) High yield production of polyhydroxyalkanoates from soybean oil by Ralstonia eutropha and its recombinant strain. Polym. Degrad. Stab. 83: 79-86.

20. Kalacheva G.S., Zhila N.O., Volova T.G. (2002) Lipid and hydrocarbon compositions of collection and wild sample of the green microalga Botryococcus. Aquatic Ecology 36: 317-330.

21. KimI.S.,BeaudetteL.A.,CassydyM.B.,LeeH., TrevorsJ.T.(2002)Alterationsinfattyacidcomposition and fluidity of cell membranes affect the accumulation of PCB congener 2,2',5,5'-tetrachlorbiphenyl by Ralstonia eutropha H850. J. Chem. Technol. Biotechnol. 77: 793-799.

22. Lee W.H., Loo C.Y., Nomura C.T., Sudesh K. (2008) Biosynthesis of polyhydroxyalkanoates copolymers from mixtures of plant oils and 3-hydroxyvalerate precursors. Biores. Technol. 99:6844-6851.

23. Lerch T.Z., Dignac M.F., Barriuso E., Bardoux G., Mariotti A. (2007) Tracing 2,4-D metabolism in Cupriavidus necator JMP134 with ${ }^{13} \mathrm{C}$-labelling technique and fatty acid profiling. J. Microb. Methods 71: 162-174. 
24. Lo K.W., Chua H., Lawford H., Lo W.H., Yu P.H.F. (2005) Effects of fatty acids on growth and poly-3-hydroxybutyrate production in bacteria. Appl. Biochem. Biotechnol. 121: 575-580.

25. Loo C.Y., Lee W.H., Tsuge T., Doi Y., Sudesh K. (2005) Biosynthesis and characterization of poly(3-hydroxybutyrate-co-3-hydroxyhexanoate) from palm oil products in a Watersia eutropha mutant. Biotechnol. Lett. 27: 1405-1410.

26. Lopez-Cuellara M.R., Alba-Floresa J., Gracida Rodrigues J.N., Perez-Guevara F. (2011) Production of polyhydroxyalkanoates (PHAs) with canola oil as carbon source. Int. J. Biol. Macromol. 48:74-80.

27. Marangoni C., Furigo A.Jr., de Aragão G.M.F. (2000) Oleic acid improves poly(3-hydroxybutyrateco-3-hydroxyvalerate) production by Ralstonia eutropha in inverted sugar and propionic acid. Biotechnol. Lett. 22: 1635-1638.

28. Muzaiyanah A.R., Amirul A.A. (2013) Studies on the microbial synthesis and characterization of polyhydroxyalkanoates containing 4-hydroxyvalerate using $\gamma$-valerolactone. Appl. Biochem. Biotechnol. 170: 1194-1215.

29. Nikodinovic-Runic J., Guzik M., Kenny S.T., Babu R., Werker A., O’Connor K.E. Carbon-rich wastes as feedstocks for biodegradable polymer (polyhydroxyalkanoates) production using bacteria. Advances in Applied Microbiology 84: 141-200.

30. Obruca S., Marova I., Snajdar O., Mravcova L., Svoboda Z. (2010) Production of poly(3hydroxybutyrate-co-3-hydroxyvalerate) by Cupriavidus necator from waste rapeseed oil using propanol as a precursor of 3-hydroyvalerate. Biotechnol. Lett. 32: 1925-1932.

31. Osterhout G.J., Valentine J.L., Dick J.D. (1998) Phenotypic and genotypic of clinical strains of CDC group IVc-2. J. Clin. Microbiol. 36: 2618-2622.

32. Parsons J.B., Rock C.O. (2013) Bacterial lipids: metabolism and membrane homeostasis. Prog. Lipid Res. 52: 249-276.

33. Ramachandran H., Amirul A.A. (2013) Yellow-pigmented Cupriavidus sp., a novel bacterium capable of utilizing glycerine pitch for the sustainable production of $\mathrm{P}(3 \mathrm{HB}-\mathrm{co}-4 \mathrm{HB})$. J. Chem. Technol. Biotechnol. 88: 1030-1038.

34. Ramachandran H., Iqbal N.M., Sipaut C.S., Amirul A.A. (2011) Biosynthesis and characterization of poly(3-hydroxybutyrate-co-3-hydroxyvalerate-co-4-hydroxybutyrate) terpolymer with various monomer compositions by Cupriavidus sp. USMAA2-4. Appl. Biochem. Biotechnol. 164: 867-877.

35. Riedel S.L., Lu J., Stahl U., Brigham C.J. (2014) Lipid and fatty acid metabolism in Ralstonia eutropha: relevance for the biotechnological production of value-added products. Appl. Microbiol. Biotechnol. 98: 1469-1483.

36. Schlegel H.G., Kaltwasser H., Gottschalk G. (1961) A submersion method for culture of hydrogenoxidizing bacteria: growth physiological studies. Arch. Mikrobiol. 38: 209-222.

37. Shantini K., Bhubalan K., Yahya A.R.M., Amirul A.A. (2013) Productivity increment of biodegradable and biorenewable copolymer containing 3-hydroxyvalerate monomer initiated by alcohols as precursor substrate. J. Chem. Technol. Biotechnol. 88: 1364-1370.

38. Srivastava S.K., Tripathi A.D. (2013) Effect of saturated and unsaturated fatty acid supplementation on bio-plastic production under submerged fermentation. Biotech. 3: 389-397.

39. Sudesh K., Bhubalan K., Chuah J.A., Kek Y.K., Kamilah H., Sridewi N., Lee Y.F. (2011) Synthesis of polyhydroxyalkanoates from palm oil and some new applications. Appl. Microbiol. Biotechnol. 89: 1373-1386. 
40. Svetashev V.I., Vaskovsky V.E. (1972) A simplified technique for thin-layer microchromatography of lipids. J. Chromatogr. 67: 376-378.

41. Thiele O.W. (1971) The lipids of hydrogen oxidizing bacteria: occurrence of cis-9,10-methylen hexadecanoic acid in Hydrogenomonas H-16. Experientia 27: 1268-1269.

42. Thiele O.W., Dreysel J., Hermenn D. (1972) The free lipids of two different strains of hydrogenoxidizing bacteria in relation to their growth phases. Eur. J. Biochem. 29: 224-236.

43. Thiele O.W., Thiele C. (1977) Lipid patterns of various hydrogen oxidizing bacterial species. Biochem. Sys. Ecol. 5: 1-6.

44. Verlinden R.A.J., Hill D.J., Kenward M.A., Williams C.D., Piotrowska-Seget Z., Radecka I.K. (2011) Production of polyhydroxyalkanoates from waste frying oil by Cupriavidus necator. AMB Express 1: 11-18.

45. Yamane T. (1992) Cultivation engineering of microbial bioplastics production. FEMS Microbiol. Rev. 103: 257-264. 